\title{
Trophic importance of epiphytic algae in subtropical seagrass beds: evidence from multiple stable isotope analyses
}

\author{
Cynthia A. Moncreiff ${ }^{1, *}$, Michael J. Sullivan ${ }^{2}$ \\ ${ }^{1}$ Department of Coastal Sciences, College of Marine Sciences, University of Southern Mississippi, Gulf Coast Research \\ Laboratory, PO Box 7000, Ocean Springs, Mississippi 39566-7000, USA \\ ${ }^{2}$ Department of Biological Sciences, PO Box GY, Mississippi State University, Mississippi State, Mississippi 39762, USA
}

\begin{abstract}
Multiple stable isotope analyses were employed to examine food web dynamics in a northern Gulf of Mexico seagrass system in which epiphytic algae were the single most important primary productivity component, being responsible for 46 and $60 \%$ of total system and benthic primary production, respectively. The seagrass Halodule wrightii Ascherson contributed only $13 \%$ to total system primary production on an annual basis. Stable isotope ratios of carbon $\left(\delta^{13} \mathrm{C}\right)$, nitrogen $\left(\delta^{15} \mathrm{~N}\right)$, and sulfur $\left(\delta^{34} \mathrm{~S}\right)$ were measured for producer and consumer samples collected from May 1989 through November 1992. Epiphytes and leaves of $H$. wrightii had distinct $\delta^{13} \mathrm{C}$ values $(-17.5$ vs $-12 \%$, respectively) as well as distinct $\delta^{34} \mathrm{~S}$ values \%o (+18 vs $+11 \%$, respectively). $\delta^{13} \mathrm{C}$ values for the sand microflora, occasional macroalgae, and phytoplankton were $-16,-17$, and $-22 \%$, respectively; $\delta^{15} \mathrm{~N}$ values were lowest for epiphytes and $H$. wrightii $(+6 \%$ ) and highest for phytoplankton $(+10 \%)$. Virtually all consumers had $\delta^{13} \mathrm{C}$ values that fell within a narrow range of -20 to $-15 \%$, which included all $\delta^{13} \mathrm{C}$ values of epiphytes and the sand microflora but none of those for either $H$. wrightii or phytoplankton. Values for $\delta^{15} \mathrm{~N}$ for consumers fell within a range of +8 to $+16 \%$, spanning herbivorous species with diets of microalgae to carnivorous species feeding at secondary to tertiary levels in the local food webs. Consumer values for $\delta^{34} \mathrm{~S}$ ranged from +4 to $+20 \%$ o (mean $=14.2 \%$ ), and indicate a stronger influence of seawater-derived sulfate than sediment-associated sulfides. The stable isotope data, in combination with measured high biomass and primary production rates of the epiphytic algae, strongly suggest that these algae are the primary source of organic matter for higher trophic levels in seagrass beds of Mississippi Sound. The contribution of $H$. wrightii to the food web appears to be minimal. The overall picture that has emerged based on the present and previous stable isotope studies is one of the major trophic importance of benthic microalgae (i.e. epiphytic and sedimentassociated) in seagrass beds.
\end{abstract}

KEY WORDS: Multiple stable isotope analyses $\cdot$ Food web $\cdot$ Seagrass $\cdot$ Trophic relationships

\section{INTRODUCTION}

Seagrass beds constitute extremely productive ecosystems in shallow coastal waters. Their complexity with regard to both structure and function is due to the great diversity and abundance of organisms present. A

*E-mail: cynthia.moncreiff@usm.edu diverse and highly productive epiphytic assemblage, composed mainly of microscopic algae, is attached to the seagrass leaf blades. This assemblage is dominated by various species of diatoms and red, brown, and green algae, and cyanobacteria (Humm 1964, Ballantine \& Humm 1975, Sullivan 1979, Thursby \& Davis 1984). Sediments beneath and adjacent to the seagrass beds are covered with a microfloral community populated primarily by species of small pennate diatoms 
(Daehnick et al. 1992). Seagrasses function as habitat for invertebrate and small vertebrate marine organisms, in addition to acting as a substrate for the epiphytic algal assemblage associated with the beds. Resident fauna associated with seagrass beds includes copepods, amphipods, isopods, shrimp, crabs, other small crustaceans, gastropods, nematodes, polychaetes, echinoderms, and small fishes (Kitting 1984, Kitting et al. 1984, Morgan \& Kitting 1984, Jernakoff et al. 1996, Jernakoff \& Nielsen 1997). Past research in coastal seagrass ecosystems indicates that the epiphytic algal assemblage may be the primary food source within this community, as opposed to the seagrasses and the detrital material they generate (Fry et al. 1982a, 1987, Fry 1984, Kitting et al. 1984, Nichols et al. 1985, Gleason 1986, Dauby 1989, 1995, Stoner \& Waite 1991, Klumpp et al. 1992, Pollard \& Kogure 1993, Yamamuro 1999).

Although food webs in seagrass systems are complex, determination of ultimate food sources via multiple stable isotope analysis can be a powerful tool for studying trophic relationships in coastal ecosystems (Fry \& Sherr 1984, Peterson et al. 1985, Fry et al. 1987, Peterson \& Howarth 1987, Sullivan \& Moncreiff 1990, Currin et al. 1995, Créach et al. 1997, Deegan \& Garritt 1997, Kwak \& Zedler 1997, Marguillier et al. 1997). The present study represents the first systematic application of the multiple stable isotope approach to study food webs in a seagrass system. The particular system in question included beds of Halodule wrightii Ascherson off Horn Island in Mississippi Sound. Moncreiff et al. (1992) found that microalgae (epiphytes, diatomdominated sand microflora, and phytoplankton) were responsible for $87 \%$ of total system primary production in these beds, with $H$. wrightii contributing only $13 \%$ on an annual basis. Epiphytic algae were the single most important productivity component, being responsible for 46 and $60 \%$ of total system and benthic primary production, respectively. The high rates of microalgal production suggest that microalgae are the primary source of organic matter for higher trophic levels in this system, and this hypothesis has been tested in the present study using stable isotope ratios of carbon, nitrogen, and sulfur.

\section{MATERIALS AND METHODS}

Study area. Horn Island is 1 of 5 islands comprising the barrier island chain off the Mississippi coast, extending approximately $22 \mathrm{~km}$ from Dog Keys Pass at its western extremity $\left(30^{\circ} 15^{\prime} \mathrm{N}, 88^{\circ} 45^{\prime} \mathrm{W}\right)$ to Horn Island Pass at its eastern end $\left(30^{\circ} 13^{\prime} \mathrm{N}, 88^{\circ} 32^{\prime} \mathrm{W}\right)$ (Fig. 1). From the coastline south of Ocean Springs, the island lies $11 \mathrm{~km}$ offshore in Mississippi Sound, sepa- rating the waters of the Sound from the Gulf of Mexico. Horn Island is hydrologically affected by drainage from the Biloxi Back Bay and the Biloxi and Pascagoula Rivers; degrees of influence are a function of discharge rates and prevailing winds. Astronomical tidal range is $0.6 \mathrm{~m}$. Upland drainage from the island proper is negligible, as the island is a sand formation and all rainfall tends to percolate into the local water table or accumulates as runoff in a series of island lagoons and marshes. During the course of this study, the shallow water $(<2 \mathrm{~m})$ sand flats on the side of Horn Island bordering Mississippi Sound were populated exclusively by beds of Halodule wrightii.

Sampling strategy. Floral and faunal samples for stable isotope analyses were collected in the Horn Island seagrass beds from May 1989 through November 1992, with most samples collected from June 1991 through November 1992 in the grass beds at the northwest end of the island (Fig. 1). These beds were fairly extensive and could be located under most environmental conditions; they were also in the same area as the beds used for the primary production measurements of Daehnick et al. (1992) and Moncreiff et al. (1992). Halodule wrightii collected during 1988 as a preliminary sample for biomass estimates prior to the latter study was also included; associated epiphyte material was insufficient for analysis.

Sample collection. All samples were placed in plastic bags or other containers with a minimal volume of water from the collection site, placed on ice, and transported to the laboratory for identification and processing. Material was frozen on return to the laboratory if immediate processing was not possible. Halodule wrightii and its associated epiphytes were collected intact in the field. Macroalgae were collected whenever encountered in sufficient quantity. Plankton samples were collected with plankton nets with mesh sizes of 28 and $153 \mu \mathrm{m}$. Nets were towed for a maximum of $10 \mathrm{~min}$; if a bloom was encountered, as many replicates as possible were collected and combined for a stable isotope sample. Tows were made parallel to the shoreline and just north of the beds at their limit of distribution to avoid possible contamination of the plankton samples with fragments of seagrass blades or epiphytes.

Sand microflora were very difficult to sample directly. We chose, instead, to represent the assemblage of diatoms and bacteria associated with the sand surface by a series of composite samples of the sand dollar Mellita quinquiesperforata. A similar approach was employed by Newell et al. (1995), who used microalgae from the stomach of the mudskipper Boleopthalmus boddaerti as stable isotope material to represent collections of sediment microalgae. Our proxy samples consisted of muscle tissues only; gut 


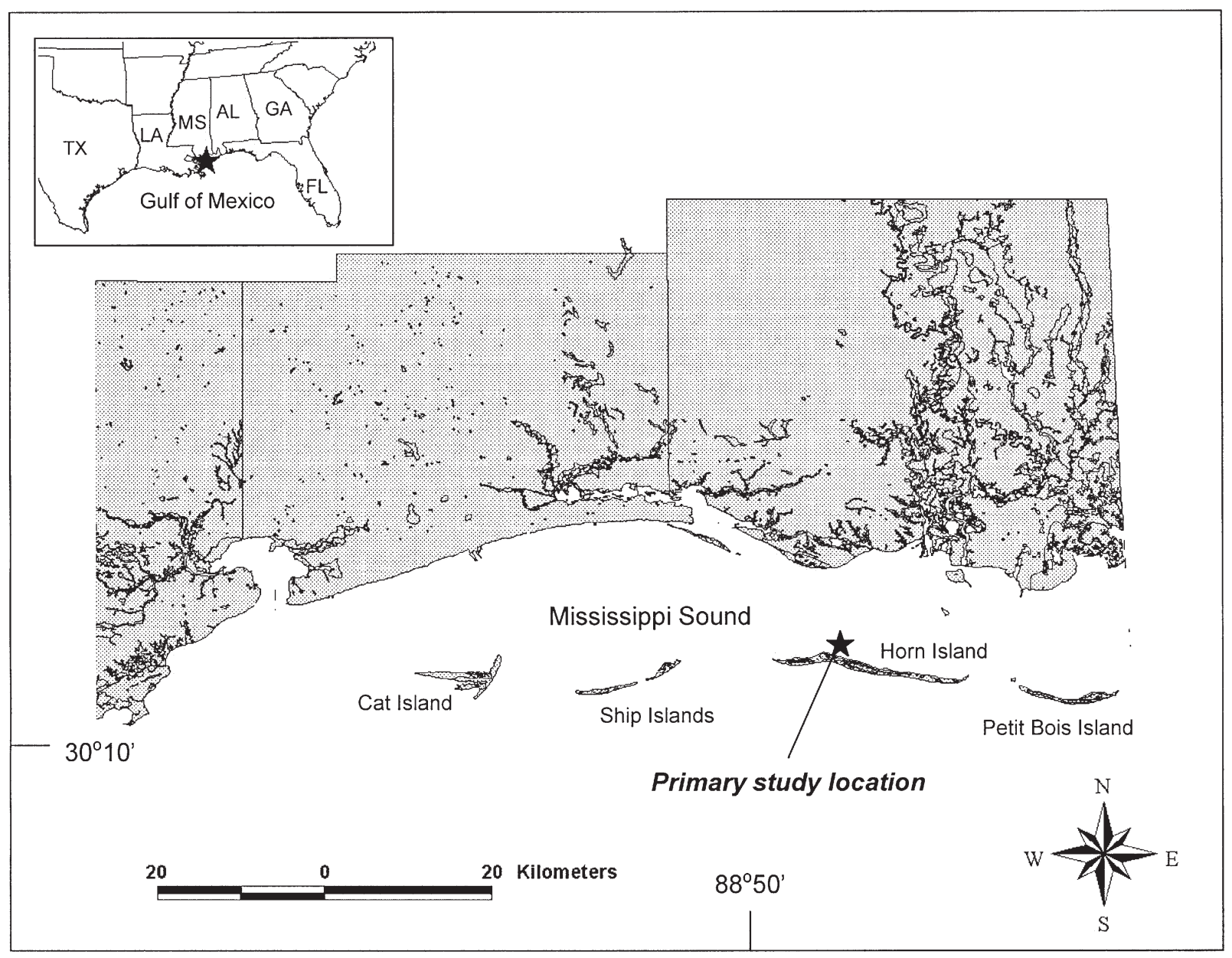

Fig. 1. Map of Mississippi Sound (USA) and the northern Gulf of Mexico indicating location of the study area

contents were discarded. Sand dollars have been reported to subsist on a diet consisting almost exclusively of sand-associated diatoms and bacteria (MacGinitie \& MacGinitie 1949, Gosner 1971, Ruppert \& Fox 1988). Sediment-associated bacteria have been shown to rely on carbon sources other than macrophyte carbon, perhaps using material of algal origin as their dominant carbon source (Boschker et al. 1999). A similar relationship could be expected in seagrass systems for bacteria also, so that any bacterial material ingested by $M$. quinquiesperforata should also have an algal-based isotopic signature. The $\delta^{13} \mathrm{C}$ value for this organism was $-16.9 \%$, which was only slightly enriched compared to the mean $\delta^{13} \mathrm{C}$ value for epiphytes. A second value for the diatom-dominated sand microflora was obtained from detritus-free substrate collected within seagrass beds; this material had a $\delta^{13} \mathrm{C}$ value of $-14.7 \%$.

Consumers were collected using several different types of sampling gear to obtain individuals represen- tative of as many microhabitats and trophic levels within the seagrass system as possible. To minimize contamination by shells or other foreign material, only live, intact organisms were included in the samples. Larger crustaceans were collected by hand from the grass beds and vicinity or in nets in conjunction with fish samples (penaeid shrimps, crabs). Smaller specimens (hippolytid shrimps Tozeuma carolinense) were collected using a beam plankton sampler (BPL), or by sieving sediments with a $1 \mathrm{~mm}$-mesh polyethylene sieve (Emerita talpoida, Haustoriidae). Gastropods, bivalves, echinoderms (primarily the sand dollar Mellita quinquiesperforata), and bryozoans were collected by hand when encountered in the grass beds and vicinity. Additional gastropod specimens were obtained from stone crab traps set at the northwest end of the island. Polychaetes were collected by sieving sediments through a $0.5 \mathrm{~mm}$-mesh polyethylene sieve. Individual polychaetes were also collected when encountered singly in seagrass or macroalgal samples. 
Fish species were collected using a variety of sampling gear, including a BPL, seines, trawls, gill nets, and cast nets.

Sample processing. All biological materials were gently rinsed with tap water to remove salts, followed by a final rinse with distilled water. In the laboratory, epiphytes were carefully scraped from fresh or frozen Halodule wrightii blades using a dull scalpel prior to drying. Microscopic examination showed that removal efficiencies were at least $95 \%$ when working with material that had been previously frozen. Although time-consuming, the efficiency of epiphyte removal by scraping has been well documented (see Fig. 5 in Dauby \& Poulicek 1995 and references therein). Macroalgae were sorted according to species and picked free of all visible meiofauna and detrital fragments. Plankton samples were examined to determine the dominant species composition, and all visible detrital material was manually removed from the samples with a fine forceps to obtain as pure a sample as possible. Cleaned plankton material was rinsed with $10 \%$ $\mathrm{HCl}$ to remove any traces of $\mathrm{CaCO}_{3}$ before rinsing with distilled water, and was then concentrated using a fine-mesh sieve (153 or $28 \mu \mathrm{m}$, depending on sample mesh size).

Consumer samples were carefully processed to minimize contamination with foreign material. Whenever possible, only muscle tissue was used to obtain consistent and comparable samples for each species or group. When contamination with $\mathrm{CaCO}_{3}$ was likely, tissues were washed in $10 \% \mathrm{HCl}$ before rinsing with tap and distilled water. Although there are some questions regarding the use of $\mathrm{HCl}$ in processing tissues for stable isotope analysis (Bunn et al. 1995), removal of $\mathrm{CaCO}_{3}$ as a contaminant was critical for some organisms, particularly gastropods that could only be sampled by crushing their shells. Chanton \& Lewis (1999) reported no significant effects on $\mathrm{C}$ or $\mathrm{N}$ stable isotope ratios as a result of using $\mathrm{HCl}$ in tissue-sample processing. Any animal tissues that required acid washing were treated prior to drying and grinding, which has much less of an effect on stable isotope ratios (Bunn et al. 1995) and in most cases is not ecologically significant (Bunn et al. 1995, Chanton \& Lewis 1999). Samples were then oven-dried to constant weight at $60^{\circ} \mathrm{C}$.

Final processing was essentially identical for all sample types. Dried samples were powdered using either a Wiley mill equipped with a \#20 or \#40 mesh delivery tube, or ground with a mortar and pestle to as fine a consistency as possible. Samples were then stored in clean, airtight glass vials, capped tightly, and packed for shipping.

The actual measurements of stable isotope ratios for all samples were performed by the Coastal Science Laboratories of Austin, Texas. The accuracy of the $\delta^{13} \mathrm{C}, \delta^{15} \mathrm{~N}$, and $\delta^{34} \mathrm{~S}$ analyses was $0.2,0.2$, and 0.5 parts per mil (\%o), respectively. A minimum of 1 blind control was included with each set of samples sent to the Coastal Science Laboratories to test the repeatability of the determinations and to insure that samples were comparable over time.

Stable isotope values were determined via mass spectroscopy by comparing samples to known standards and recording the difference between the sample and the appropriate standard in parts per thousand or per mil (\%) according to the formula

$$
\delta X=\left[\left(R_{\text {sample }} / R_{\text {standard }}\right)-1\right] \times 10^{3}
$$

where $X$ is ${ }^{13} \mathrm{C},{ }^{15} \mathrm{~N}$, or ${ }^{34} \mathrm{~S}$, and $R$ is ${ }^{13} \mathrm{C} /{ }^{12} \mathrm{C},{ }^{15} \mathrm{~N} /{ }^{14} \mathrm{~N}$ or ${ }^{34} \mathrm{~S} /{ }^{32} \mathrm{~S}$. Standards for $\mathrm{C}, \mathrm{N}$, and $\mathrm{S}$ are PeeDee belemnite, atmospheric diatomic nitrogen, and Canyon Diablo troilite, respectively.

Trophic levels were calculated for selected samples according to the approach of Hobson \& Welch (1992) using values determined for this seagrass system, and their equation for the prediction of trophic level:

$$
T L=1+\left(N_{\mathrm{m}}-7.0\right) / 3.0
$$

where $T L$ is the trophic level of the consumer, $N_{\mathrm{m}}$ is the $\delta^{15} \mathrm{~N}$ value for muscle tissue of the organism (samples of small whole organisms could also be used in this equation as values are comparable), and the values 7.0 and $3.0 \%$ are the estimates for POM and a trophic enrichment factor for this seagrass system, respectively.

\section{RESULTS}

\section{Stable isotope ratios of producers}

Stable carbon isotope ratios of Halodule wrightii and its associated epiphytes (mainly araphid and biraphid diatom taxa and the red alga Acrochaetium flexuosum Vickers) were distinct (Table 1). The mean $\delta^{13} \mathrm{C}$ value for $H$. wrightii was $-12.2 \%$ (range $=-13.6$ to $-10.6 \%$ ), while that for epiphytes was $-17.5 \%$ (range $=-19.7$ to $-15.2 \%$ ). Thus, there was very good separation between these critical samples. The sand microflora (almost exclusively small, pennate diatoms), represented by proxy samples of the sand dollar Mellita quinquiesperforata and by detritus-free, diatom-rich seagrass substrate, had an average $\delta^{13} \mathrm{C}$ value of $-15.8 \%$, which was only slightly enriched compared to the mean $\delta^{13} \mathrm{C}$ value for epiphytes. Phytoplankton, represented by plankton samples consisting of a mixture of diatoms and copepods, had a mean $\delta^{13} \mathrm{C}$ value of $-21.8 \%$, with a range of -23.3 to $-21.2 \%$. Thus, phytoplankton values were reasonably well separated from those for epiphytes and particularly $H$. wrightii blades. 
Macroalgal species had $\delta^{13} \mathrm{C}$ values which ranged from -17.4 to $-16.2 \%$; this range overlapped $\delta^{13} \mathrm{C}$ values for epiphytes and sand microflora (Table 1).

Stable nitrogen isotope ratios were similar for Halodule wrightii, its epiphytes, and the sand microflora as mean values ranged from +5.9 to $+7.2 \%$ (Table 1 ). The plankton samples had $\delta^{15} \mathrm{~N}$ values that were consistently higher than those of the above 3 producers (range $=+8.2$ to $11.1 \%$, mean $=+9.9 \%$ o). $\delta^{15} \mathrm{~N}$ values for the macroalgae showed the greatest variability and ranged from +4.5 to $10.0 \%$, with a mean value of $7.0 \%$ for the 4 species.

Stable sulfur isotope ratios were much more variable than those for carbon or nitrogen (Table 1). The mean $\delta^{34} \mathrm{~S}$ value for Halodule wrightii was $+11.5 \%$ and for its epiphytes $+18.2 \%$. However, the range of these values was greater for the former ( 7.6 compared to $4.1 \%$ ). The sand microflora had the lowest $\delta^{34} \mathrm{~S}$ value $\left(+10.6 \%\right.$ ). The mean $\delta^{34} \mathrm{~S}$ value for the macroalgae was identical to that for epiphytes $\left(+18.2 \%\right.$ ) as was the range, whereas $\delta^{34} \mathrm{~S}$ values for phytoplankton (mean $=+15.4 \%$, range $=$ +11.5 to $+17.6 \%$ ) were intermediate between those for $H$. wrightii and its epiphytes.

\section{Stable isotope ratios of consumers}

Table 2 summarizes the $\delta^{13} \mathrm{C}$ data for consumers of the Horn Island seagrass beds; all values in this table are means. The individual $\delta^{13} \mathrm{C}$ values for each of 186 consumer samples, as well as matching values for $\delta^{15} \mathrm{~N}$ and $\delta^{34} \mathrm{~S}$, can be found in Appendix A of Sullivan \& Moncreiff (1993); like values for all primary producer samples are also given here. Stable carbon isotope ratios for individual organisms ranged from $-23.0 \%$ for the Atlantic croaker Micropogon undulatus to $-12.7 \%$ for the white mullet Mugil curema. When averaged by species or sample type, a pooled sample of miscellaneous small shrimp species exhibited the highest $\delta^{13} \mathrm{C}$ value $(-13.5 \%)$ and the white trout Cynoscion arenarius the lowest $(-21.0 \%)$. The mean $\delta^{13} \mathrm{C}$ value for all consumers sampled was $-17.3 \%$. A total of 129 out of 186 $(70 \%)$ consumer samples in this system had $\delta^{13} \mathrm{C}$ values falling within a range of -18.8 to $-15.4 \%$. All but 13 of the 186 (93\%) consumer samples fell within a range of -20.1 to $-14.1 \%$. Neither of these ranges includes the mean $\delta^{13} \mathrm{C}$ values of -12.2 and $-21.8 \%$ for Halodule wrightii and phytoplankton, respectively. Tissues of consumer species mirror their diet with respect to $\delta^{13} \mathrm{C}$, although enrichment of $1 \%$ may occur from one trophic level to the next (DeNiro \& Epstein 1978, Fry 1984, Peterson et al. 1985, 1986, Currin et al. 1995).
Table 1. $\delta^{13} \mathrm{C}, \delta^{15} \mathrm{~N}$, and $\delta^{34} \mathrm{~S}$ values (\%) for primary producers in seagrass beds of Horn Island. $\bar{x}=$ mean; $\mathrm{SD}=$ standard deviation nd $=$ not determined

\begin{tabular}{|c|c|c|c|}
\hline Producer & $\delta^{13} \mathrm{C}$ & $\delta^{15} \mathrm{~N}$ & $\delta^{34} \mathrm{~S}$ \\
\hline \multicolumn{4}{|l|}{ Halodule wrightii } \\
\hline 1988 sample & -13.6 & 6.4 & 15.0 \\
\hline 1989-90 sample & -12.9 & 5.7 & 15.0 \\
\hline 1991 sample & -10.6 & 4.6 & 7.4 \\
\hline 1992 sample & -11.7 & 7.5 & 8.5 \\
\hline $\bar{X}$ & -12.2 & 6.0 & 11.5 \\
\hline $\mathrm{SD}$ & 1.2 & 1.1 & 3.5 \\
\hline \multicolumn{4}{|l|}{ Epiphytic algae } \\
\hline 1989-90 sample & -18.5 & 6.9 & 18.3 \\
\hline 1991 sample & -15.2 & 6.2 & nd \\
\hline 1992 sample & -16.8 & 4.4 & 16.1 \\
\hline 1992 sample & -19.7 & 5.9 & 20.2 \\
\hline $\bar{X}$ & -17.5 & 5.9 & 18.2 \\
\hline $\mathrm{SD}$ & 1.7 & 0.9 & 2.1 \\
\hline \multicolumn{4}{|l|}{ Sand microflora proxies } \\
\hline Mellita quinquiesperforata (1992) & -16.9 & 6.7 & 8.6 \\
\hline $\begin{array}{l}\text { Diatom-rich seagrass substrate } \\
\text { (1992) }\end{array}$ & -14.7 & 7.8 & 12.6 \\
\hline $\bar{X}$ & -15.8 & 7.2 & 10.6 \\
\hline $\mathrm{SD}$ & 1.1 & 0.6 & 2.0 \\
\hline \multicolumn{4}{|l|}{ Phytoplankton } \\
\hline 1991 sample & -23.3 & 8.2 & 11.5 \\
\hline $1992,28 \mu \mathrm{m}$ & -21.3 & 9.8 & 13.0 \\
\hline $1992,28 \mu \mathrm{m}$ & -21.6 & 10.4 & 17.6 \\
\hline $1992,153 \mu \mathrm{m}$ & -21.7 & 10.0 & 16.7 \\
\hline $1992,153 \mu \mathrm{m}$ & -21.2 & 10.0 & 15.9 \\
\hline 1992, mixed & -21.5 & 11.1 & 17.6 \\
\hline $\bar{X}$ & -21.8 & 9.9 & 15.4 \\
\hline $\mathrm{SD}$ & 0.7 & 0.9 & 2.3 \\
\hline \multicolumn{4}{|l|}{ Macroalgae } \\
\hline Enteromorpha sp. & -16.2 & 8.8 & 20.4 \\
\hline Sargassum natans & -16.8 & 4.7 & 17.8 \\
\hline Sargassum fluitans & -16.6 & 4.5 & 17.9 \\
\hline Gracilaria verrucosa & -17.4 & 10.0 & 16.6 \\
\hline $\bar{X}$ & -16.8 & 7.0 & 18.2 \\
\hline $\mathrm{SD}$ & 0.5 & 2.8 & 1.6 \\
\hline
\end{tabular}

Stable nitrogen isotope ratios, indicative of trophic level, ranged from $+6.0 \%$ for the white mullet Mugil curema (a different specimen from that producing the lowest $\delta^{13} \mathrm{C}$ value) to $+16.6 \%$ for the bluefish Pomatomus saltatrix for individual organisms. Averaging $\delta^{15} \mathrm{~N}$ values for consumers by species or sample type showed the bivalve Tellina alternata to occupy the lowest trophic position at $7.5 \%$, and the estuarine squid Lolliguncula brevis with a value of $15.7 \%$ o to occupy the highest position (Table 2). The mean $\delta^{15} \mathrm{~N}$ value for all consumers sampled was $+12.5 \%$.

Hobson \& Welch (1992) employed $\delta^{15} \mathrm{~N}$ values in an Arctic marine food web to determine trophic levels using values measured for a known set of predators (polar bears) and their prey (ringed seals). A similar approach 


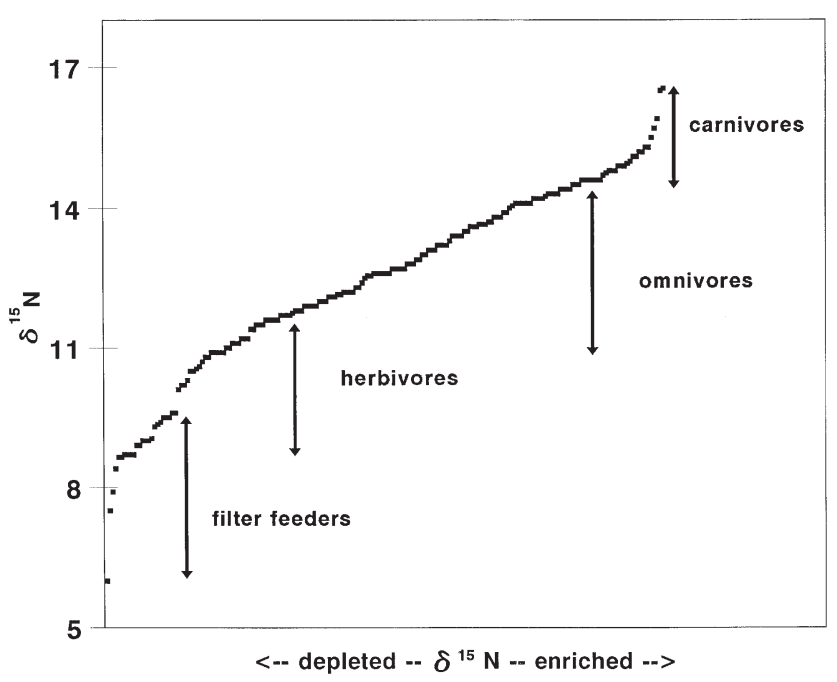

Fig. 2. Plot of $\delta^{15} \mathrm{~N}(\%)$ for all consumer samples collected in 1991 and 1992 (combined data) from Horn Island seagrass beds

can be taken in this subtropical seagrass system. Averaging the $\delta^{15} \mathrm{~N}$ values for all primary producers, excluding the plankton, yielded an estimate of $+7.0 \pm 1.8 \%$ ofor POM as a 'baseline' value to establish where TL1 lies. Using the previously described equation of Hobson \& Welch as adapted for this seagrass system (Eq. 2), the shark species sampled lie at TL 3.5. An average $\delta^{15} \mathrm{~N}$ value of $+10.3 \%$ for the plankton samples collected on 10 July 1992, a large fraction of which were copepods, places this set of samples at TL 2.1. The estuarine squid Lolliguncula brevis and the bluefish Pomatomus saltatrix, with the highest $\delta^{15} \mathrm{~N}$ values, lie at TL 3.9. Thus, this type of model seems to work well for this system, which has no obvious demarcations between trophic levels as there are very few breaks in the cascade of the $\delta^{15} \mathrm{~N}$ values shown in Fig. 2. General consumer groups are also indicated in this figure.

Stable sulfur isotope ratios of consumers ranged from $+2.3 \%$ for the white mullet Mugil curema to $+19.6 \%$ for the moon jellyfish Aurelia aurita for individual samples. The observed range in $\delta^{34} \mathrm{~S}$ values when averaged by species or sample type was $+4.4 \%$ for beach diggers in the family Haustoriideae to $+19.6 \%$ or $A$. aurita. The mean $\delta^{34} \mathrm{~S}$ value for all consumers sampled was $+14.2 \%$. Stable sulfur isotope ratios of consumers tend to closely reflect their diets (Peterson et al. 1985, 1986). The observed range and average for consumer $\delta^{34} \mathrm{~S}$ values indicates that a variety of algal food sources are being used by the organisms found within the seagrass beds. A diet consisting of a mix of food items including epiphytic algae, sand microflora, and phytoplankton in equal amounts would have a $\delta^{34} \mathrm{~S}$ value of $+14.7 \%$, which is very close to the average value for all con- sumers. However, the results do not rule out the potential for indirect contributions of seagrass to the overall food web, perhaps as detritus, as is the case for Spartina alterniflora in North Carolina (Currin at al. 1995).

\section{Dual isotope plots}

A series of dual isotope plots of $\delta^{13} \mathrm{C}$ vs $\delta^{15} \mathrm{~N}$ and $\delta^{13} \mathrm{C}$ vs $\delta^{34} \mathrm{~S}$ were generated from the pool of stable isotope data. Fig. 3 is a $\delta^{13} \mathrm{C}$ vs $\delta^{15} \mathrm{~N}$ plot for all consumers sapled during the study. There was a close match between the 1991 and 1992 samples, except for a slightly tighter clustering of the former. This, however, may simply be an artifact of the number of samples analyzed from each year (125 in 1991 vs 53 in 1992). As the majority of consumer organisms sampled were at least $1 \mathrm{yr}$ old, the consumers were 'averaging out' seasonal and interannual differences in $\delta^{13} \mathrm{C}$ and $\delta^{15} \mathrm{~N}$ values among the potential sources of organic matter listed in Table 1. Fig. 4 plots $\delta^{13} \mathrm{C}$ vs $\delta^{34} \mathrm{~S}$ values for all 1991 and 1992 consumer samples and reveals essentially the same pattern as seen in Fig. 3. The greatest disparity between years involved organisms with low $\delta^{34} \mathrm{~S}$ values; however, the majority of these were either sampled in 1 yr only or were collected from the nearby beach rather than from Halodule wrightii beds. Again, it is assumed that consumers greater than 1 yr old were exposed to all seasonal differences in $\delta^{13} \mathrm{C}$ and $\delta^{34} \mathrm{~S}$ values of potential organic matter sources.

The $\delta^{13} \mathrm{C}$ vs $\delta^{15} \mathrm{~N}$ plots shown in Fig. 5 include the primary producer samples listed in Table 1 and all consumer samples collected in 1991 and 1992. In both

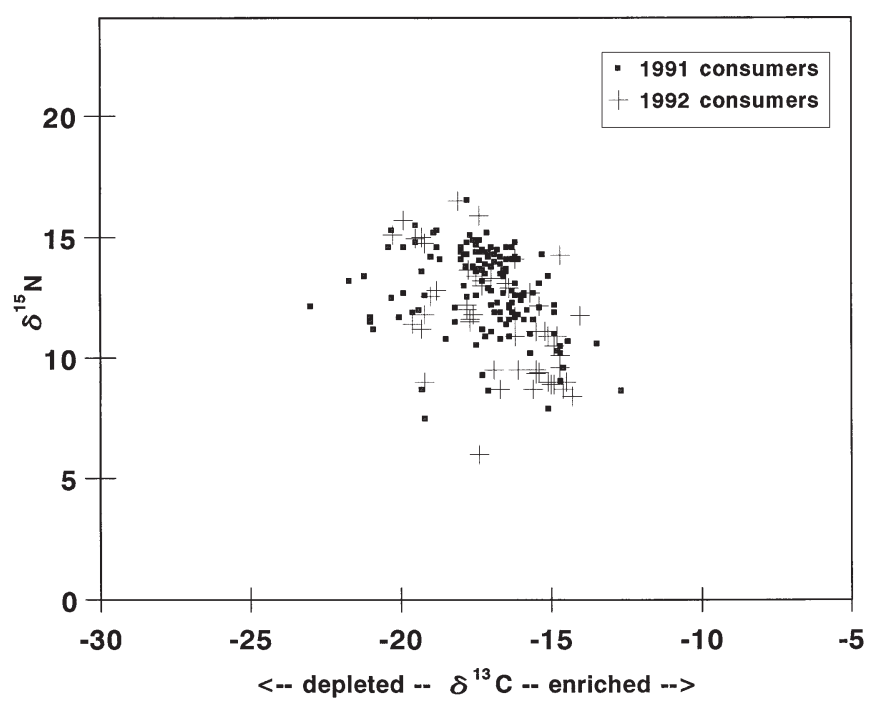

Fig. 3. Plot of $\delta^{13} \mathrm{C}$ vs $\delta^{15} \mathrm{~N}$ (\%) for all consumer samples collected in 1991 and 1992 from Horn Island seagrass beds 


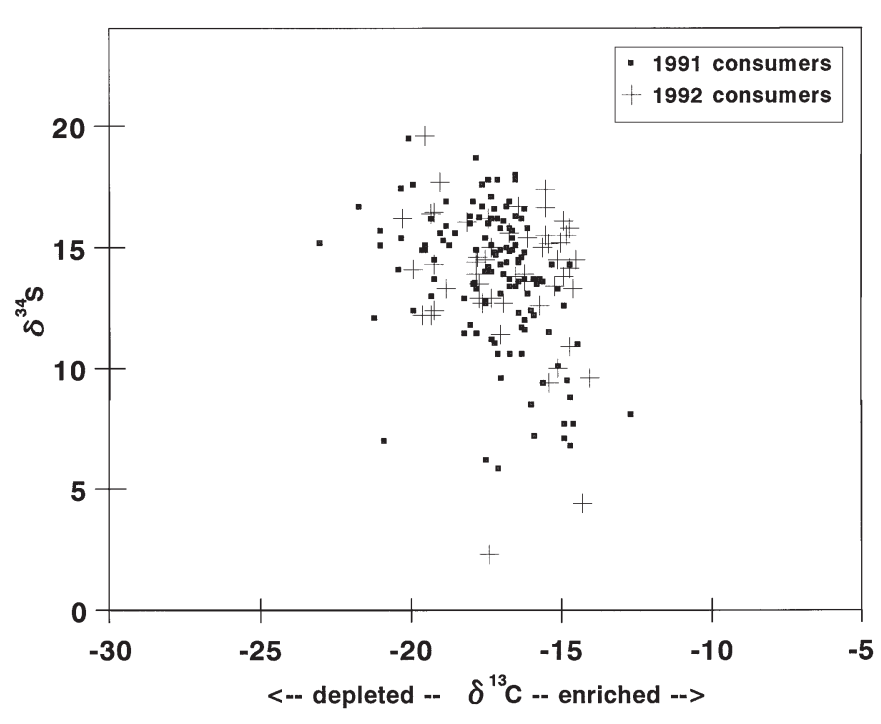

Fig. 4. Plot of $\delta^{13} \mathrm{C}$ vs $\delta^{34} \mathrm{~S}(\%)$ for all consumer samples collected in 1991 and 1992 from Horn Island seagrass beds

plots, the $\delta^{13} \mathrm{C}$ values for virtually all consumers fall within a range of -20 to $-15 \%$; this range includes all $\delta^{13} \mathrm{C}$ values for epiphytic algae, sand microflora, and macroalgae but none of those for Halodule wrightii or phytoplankton. Neither plot reveals any discontinuities in the $\delta^{15} \mathrm{~N}$ data for consumers, but rather a continuum of values; hence, delineation of distinct trophic levels is not possible in this data set.

Fig. 6 shows dual isotope plots of the $\delta^{13} \mathrm{C}$ vs $\delta^{34} \mathrm{~S}$ data for primary producers and consumers in 1991 and 1992. Virtually all data points for consumers in both years are bracketed by the epiphytic algae, sand microflora, and macroalgae. The data points for Halodule wrightii and phytoplankton are outliers.

\section{DISCUSSION}

\section{Stable isotope ratios of producers}

Stable carbon isotope values for Halodule wrightii and for its epiphytes in Mississippi Sound fell within the range of previously reported values for at least 8 species of seagrasses (Table 3). Hemminga \& Mateo (1996) summarized $\delta^{13} \mathrm{C}$ values from the literature for 195 seagrass values, and reported an average value of $-11 \%$ for all species, with values ranging from -12 to $-11.2 \%$ for Halodule species based on the work of McMillan et al. (1980); we found a mean value of $-12.2 \%$ (Table 1). As previously stated, the $\delta^{13} \mathrm{C}$ value for the sand microflora $(-15.8 \%$ ) was the average for samples of the sand dollar Mellita quinquiesperforata and a diatom-dominated seagrass-substrate sample.
Dauby (1995) recorded a mean $\delta^{13} \mathrm{C}$ value of $-18.0 \%$ for the sand microflora (mostly diatoms) in a Posidonia oceanica (L.) Delile bed, while Stoner \& Waite (1991) reported $-19 \%$ for a cyanobacterial mat in a Bahamas seagrass bed. Phytoplankton in Mississippi Sound had a mean $\delta^{13} \mathrm{C}$ value of $-21.8 \%$, very close to the $-23 \%$ reported by Sullivan \& Moncreiff (1990) for a pure zooplankton sample collected in Graveline Bay Marsh $11 \mathrm{~km}$ to the north of the Horn Island seagrass beds.

Stable nitrogen isotope values were essentially identical for Halodule wrightii, its epiphytes, and the sand microflora (means $=+6$ to $+7 \%$; see our Table 1 ). The absence of cyanobacteria from $H$. wrightii leaves
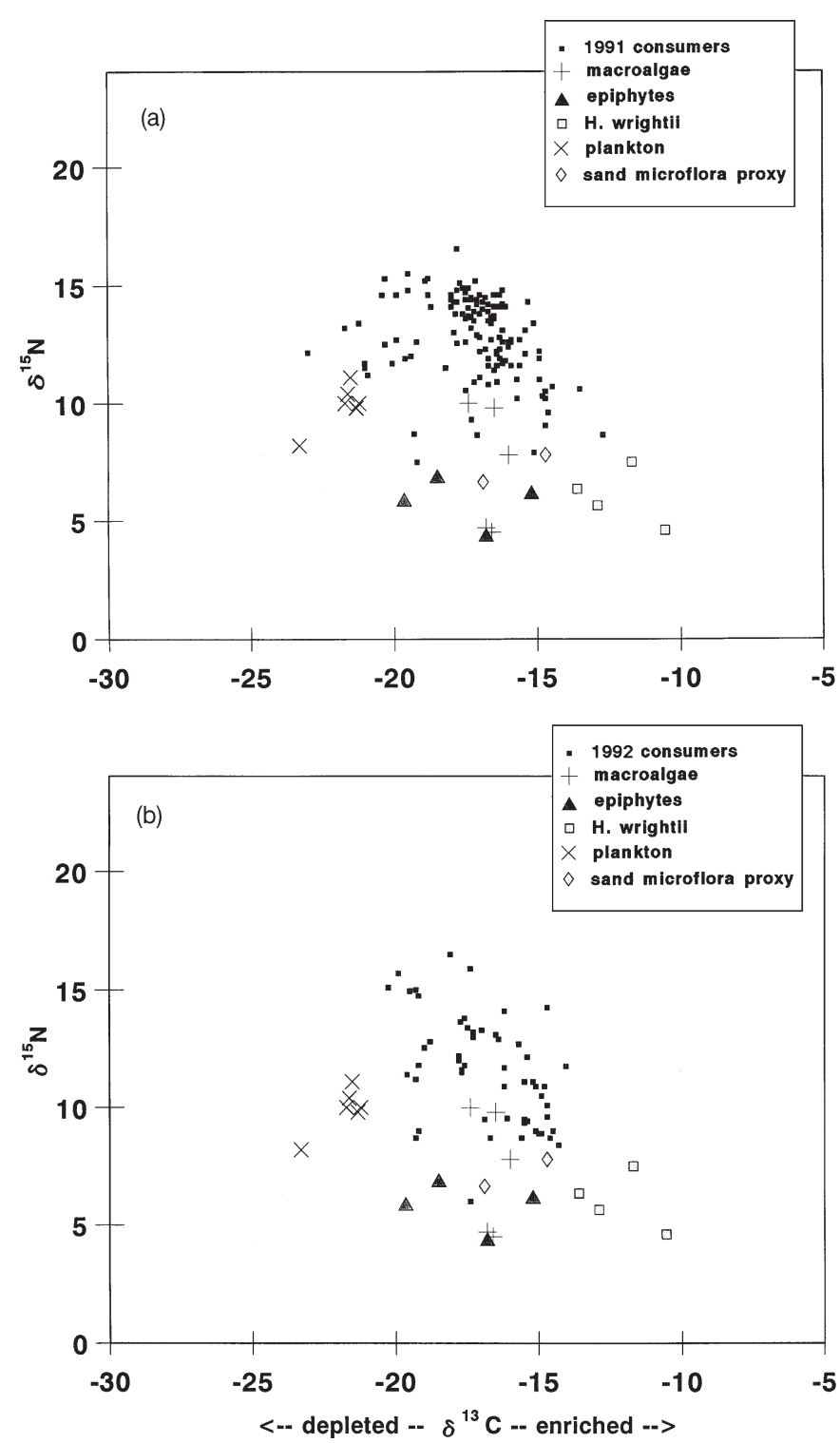

Fig. 5. Plots of $\delta^{13} \mathrm{C}$ vs $\delta^{15} \mathrm{~N}$ (\%) for primary producers and consumers collected from Horn Island seagrass beds in (a) 1991 and (b) 1992. Each small square represents an individual consumer sample 
in Mississippi Sound (Moncreiff et al. 1992) eliminated the possibility of nitrogen-fixing cyanobacteria in the epiphytic assemblage influencing the $\delta^{15} \mathrm{~N}$ values of seagrass leaves (Fry et al. 1987). In contrast, Yamamuro (1999) reported a range in $\delta^{15} \mathrm{~N}$ values of -2 to $-1 \%$ for a cyanobacteria-dominated epiphytic assemblage on the seagrass $S y-$ ringodium isoetifolium Dandy. Phytoplankton had a mean $\delta^{15} \mathrm{~N}$ value of $+10 \%$ o which compares well to values of $+7 \%$ (Sullivan \& Moncreiff 1990), +8\% (Fry et al. 1987), and $+9 \%$ (Peterson \& Howarth 1987).

Stable sulfur isotope values of Halodule wrightii and its epiphytes were distinct (mean $\delta^{34} \mathrm{~S}$ values $=+11$ and $+18 \%$, respectively; see our Table 1) in Mississippi Sound. Macroalgae collected in Mississippi Sound had the same mean $\delta^{34} \mathrm{~S}$ value and range of values as the epiphytes. This closely approximates the situation in Texas seagrass beds (Fry et al. 1982b; see also Table 10 in Fry et al. 1987). Thus, epiphytes and macroalgae obtain more of their sulfur from seawater sulfate $\left(\delta^{34} \mathrm{~S}=+20 \%\right.$ ) than do seagrass leaves, which obtain at least some of their sulfur from $\delta^{34} \mathrm{~S}$-depleted sulfides (range $=-30$ to $-10 \%$ ) following uptake from the sediments by the roots. Phytoplankton in Mississippi Sound had a mean $\delta^{34} \mathrm{~S}$ value of $+15 \%$, which is intermediate between values of $+11 \%$ measured for a pure zooplankton sample in Graveline Bay Marsh by Sullivan \& Moncreiff (1990) and $+19 \%$ for a plankton sample from Woods Hole Passage by Peterson et al. $(1985,1986)$. The $\delta^{34} \mathrm{~S}$ value of $+10.6 \%$ for the sand microflora proxies of the Horn Island seagrass beds is more depleted in $\delta^{34} \mathrm{~S}$ than the value of $+14 \%$ obtained for edaphic algae of Graveline Bay Marsh by Sullivan \& Moncreiff (1990). However, Currin et al. (1995) reported a $\delta^{34} \mathrm{~S}$ value of $+4 \%$ o for sediment-associated microalgae of a North Carolina salt marsh. A notable problem with these 3 measurements is that $\mathrm{n}=1$ for the cited studies and $\mathrm{n}=2$ for the present study, so that the variability in benthic microalgal $\delta^{34} \mathrm{~S}$ values is unknown.
Table 2. Summary of mean $\delta^{13} \mathrm{C}, \delta^{15} \mathrm{~N}$, and $\delta^{34} \mathrm{~S}$ values (\%o) for consumers in seagrass beds of Horn Island. Organisms are arranged by functional groups. See Sullivan \& Moncreiff (1993) for complete sample record. nd = not determined; $\mathrm{n}=$ number of individual organisms sampled

\begin{tabular}{|c|c|c|c|}
\hline Consumer group, species, and common name & $\delta^{13} \mathrm{C}$ & $\delta^{15} \mathrm{~N}$ & $\delta^{34} \mathrm{~S}$ \\
\hline \multicolumn{4}{|l|}{ Planktivorous fish species } \\
\hline Anchoa mitchilli (bay anchovy), $\mathrm{n}=119$ & -19.1 & 14.8 & 16.7 \\
\hline Anchoa nasuta (longnose anchovy), $\mathrm{n}=24$ & -18.4 & 14.3 & 17.0 \\
\hline Brevoortia patronus (Gulf menhaden), $\mathrm{n}=2$ & -19.6 & 11.9 & 14.9 \\
\hline Harengula jaguana (scaled sardine), $\mathrm{n}=220$ & -18.2 & 13.1 & 17.8 \\
\hline Larval clupeids, $\mathrm{n}=35$ & -19.4 & 12.0 & nd \\
\hline Menidia beryllina (tidewater silverside), $\mathrm{n}=69$ & -17.1 & 13.0 & 13.3 \\
\hline Non-clupeid larval fish, $\mathrm{n}=137$ & -15.7 & 10.2 & nd \\
\hline \multicolumn{4}{|l|}{ Benthic carnivorous fish species } \\
\hline $\begin{array}{l}\text { Ancyclopsetta quadrocellata } \\
\text { (ocellated flounder), } \mathrm{n}=2\end{array}$ & -16.0 & 13.7 & 13.6 \\
\hline Dasyatis sabina (Atlantic stingray), $\mathrm{n}=4$ & -16.2 & 12.2 & 12.1 \\
\hline Citharichthys spilopterus (bay whiff), $\mathrm{n}=16$ & -16.8 & 13.1 & 15.4 \\
\hline Cynoscion arenarius (white trout), $\mathrm{n}=2$ & -21.0 & 14.2 & 16.5 \\
\hline Diplectrum bivitattum (dwarf sand perch), $\mathrm{n}=29$ & -17.5 & 13.4 & 15.4 \\
\hline Diplectrum formosum (sand perch), $\mathrm{n}=4$ & -17.1 & 14.2 & 16.2 \\
\hline Eucinostomus argenteus (spotfin mojarra), $\mathrm{n}=17$ & -17.8 & 12.5 & 11.5 \\
\hline Gymnothorax ocellatus (ocellated moray), $\mathrm{n}=1$ & -17.5 & 14.4 & 14.0 \\
\hline Lutjanus campechanus (red snapper), $\mathrm{n}=12$ & -16.8 & 14.1 & 15.8 \\
\hline Lutjanus griseus (gray snapper), $\mathrm{n}=3$ & -20.1 & 14.4 & 14.0 \\
\hline Lutjanus synagris (candy snapper), $\mathrm{n}=3$ & -16.7 & 14.2 & 16.9 \\
\hline Menticirrhus americanus (southern kingfish), $\mathrm{n}=3$ & -15.8 & 13.8 & 14.7 \\
\hline Micropogon undulatus (Atlantic croaker), $\mathrm{n}=5$ & -20.1 & 12.7 & 13.5 \\
\hline Prionotus tribulus (bighead sea robin), $\mathrm{n}=8$ & -16.5 & 13.4 & 14.2 \\
\hline Sciaenops ocellata (redfish), $\mathrm{n}=2$ & -16.2 & 11.4 & 6.7 \\
\hline Sphoeroides parvus (least puffer), $\mathrm{n}=10$ & -17.2 & 13.5 & 14.8 \\
\hline Symphurus plagiusa (blackcheek tonguefish), $\mathrm{n}=13$ & -18.2 & 12.7 & 13.1 \\
\hline Synodus foetens (inshore lizardfish), $\mathrm{n}=5$ & -17.0 & 15.3 & 17.0 \\
\hline \multicolumn{4}{|l|}{ Pelagic carnivorous fish species } \\
\hline Chaetodipterus faber (Atlantic spadefish), $\mathrm{n}=3$ & -19.2 & 14.9 & 15.9 \\
\hline Chloroscombrus chrysurus (Atlantic bumper), $\mathrm{n}=3$ & -17.8 & 14.5 & 17.4 \\
\hline Cynoscion nebulosus (speckled trout), $\mathrm{n}=3$ & -17.5 & 14.6 & 12.4 \\
\hline Elops saurus (ladyfish), $\mathrm{n}=3$ & -19.5 & 12.7 & 9.4 \\
\hline Echeneis neucratoides (sharksucker), $\mathrm{n}=2$ & -17.4 & 14.1 & 14.2 \\
\hline Pomatomus saltatrix (bluefish), $\mathrm{n}=3$ & -18.9 & 15.6 & 15.0 \\
\hline Strongylura marina (Atlantic needlefish), $\mathrm{n}=1$ & -19.9 & 14.6 & 17.6 \\
\hline Trachinotus carolinus (Florida pompano), $\mathrm{n}=7$ & -19.4 & 12.2 & 14.9 \\
\hline Scomberomorus maculatus (Spanish mackerel), $\mathrm{n}=1$ & -17.7 & 15.1 & 16.3 \\
\hline \multicolumn{4}{|l|}{ Carnivorous/benthic scavengers } \\
\hline Arius felis (hardhead catfish), $\mathrm{n}=25$ & -17.0 & 13.6 & 11.6 \\
\hline $\begin{array}{l}\text { Rhizoprionodon terranovae } \\
\quad \text { (Atlantic sharpnose shark), } \mathrm{n}=3\end{array}$ & -16.9 & 14.8 & 15.2 \\
\hline Sphyrna tiburo (bonnethead shark), $\mathrm{n}=4$ & -16.3 & 14.5 & 15.6 \\
\hline \multicolumn{4}{|l|}{ ‘Generic' omnivorous fish species } \\
\hline Balistes capriscus (gray triggerfish), $\mathrm{n}=1$ & -16.7 & 11.9 & 15.8 \\
\hline Leiostomus xanthurus (spot; flat croaker), $\mathrm{n}=4$ & -17.4 & 13.5 & 13.8 \\
\hline Monacanthus setifer (pygmy filefish), $\mathrm{n}=1$ & -17.0 & 12.8 & 15.8 \\
\hline \multicolumn{4}{|l|}{ Benthic omnivorous fish species } \\
\hline Fundulus similis (longnose killifish), $\mathrm{n}=10$ & -14.1 & 11.8 & 9.6 \\
\hline Lagodon rhomboides (pinfish), $\mathrm{n}=13$ & -16.1 & 12.2 & 11.8 \\
\hline Mugil cephalus (striped mullet), $\mathrm{n}=3$ & -14.6 & 10.2 & 9.2 \\
\hline Mugil curema (white mullet), $\mathrm{n}=6$ & -15.7 & 9.8 & 9.6 \\
\hline Orthopristis chrysoptera (pigfish), $\mathrm{n}=2$ & -16.5 & 13.5 & 12.7 \\
\hline
\end{tabular}


Table 2 (continued)

\begin{tabular}{|c|c|c|c|}
\hline Consumer group, species, and common name & $\delta^{13} \mathrm{C}$ & $\delta^{15} \mathrm{~N}$ & $\delta^{34} \mathrm{~S}$ \\
\hline \multicolumn{4}{|l|}{ Benthic/pelagic crabs and crustaceans } \\
\hline Callinectes sapidus (blue crab), $\mathrm{n}=11$ & -18.0 & 13.1 & 14.7 \\
\hline Chelonibia patula (crab barnacle), $\mathrm{n}=25$ & -20.1 & 11.7 & 19.5 \\
\hline Hepatus epheliticus (calico box crab), $\mathrm{n}=2$ & -16.2 & 14.1 & 15.8 \\
\hline Libinia dubia (spider crab), $\mathrm{n}=2$ & -17.2 & 13.9 & 16.6 \\
\hline Libinia emarginata (spider crab), $\mathrm{n}=2$ & -17.3 & 13.7 & 17.1 \\
\hline Menippe mercenaria (stone crab), $\mathrm{n}=1$ & -16.5 & 14.1 & 18.0 \\
\hline Portunus gibbesii (purple swimming crab), $\mathrm{n}=18$ & -17.3 & 13.2 & 15.1 \\
\hline \multicolumn{4}{|l|}{ Nearshore crabs and crustaceans } \\
\hline Clibanarius vittatus (striped hermit crab), $\mathrm{n}=72$ & -15.1 & 9.6 & 15.7 \\
\hline Emerita talpoida (common mole crab), n = 191 & -15.3 & 8.9 & 14.7 \\
\hline Haustoriidae (beach diggers), $\mathrm{n}>100$ & -14.3 & 8.4 & 4.4 \\
\hline Limulus polyphemus (horseshoe crab), $\mathrm{n}=5$ & -15.7 & 12.1 & 13.1 \\
\hline Pagurus pollicaris (flat-clawed hermit crab), $\mathrm{n}=25$ & -15.6 & 11.6 & 15.0 \\
\hline \multicolumn{4}{|l|}{ Shrimp species } \\
\hline Hippolytid shrimp, $\mathrm{n}>1,500$ & -15.1 & 7.9 & 10.1 \\
\hline Miscellaneous small shrimp, $\mathrm{n}=203$ & -13.5 & 10.6 & nd \\
\hline Mysids, $\mathrm{n}>500$ & -15.9 & 9.6 & 6.3 \\
\hline Farfantepenaeus aztecus (brown shrimp), $\mathrm{n}=40$ & -17.7 & 11.0 & 11.8 \\
\hline Farfantepenaeus duorarum (pink shrimp), n = 8 & -16.5 & 11.2 & 12.1 \\
\hline Litopenaeus setiferus (white shrimp), $\mathrm{n}=3$ & -19.6 & 11.4 & 12.2 \\
\hline Sicyonia brevirostris (brown rock shrimp), $\mathrm{n}=9$ & -16.4 & 10.9 & 14.4 \\
\hline Squilla empusa (mantis shrimp), $\mathrm{n}=23$ & -16.9 & 13.1 & 14.6 \\
\hline Tozeuma carolinense (arrow shrimp), $\mathrm{n}=297$ & -14.7 & 10.1 & 10.9 \\
\hline Rimapenaeus constrictus (roughneck shrimp), n = 29 & -16.7 & 11.4 & 13.2 \\
\hline Rimapenaeus similis (yellow roughneck shrimp), $\mathrm{n}=97$ & $7-17.9$ & 11.8 & 13.5 \\
\hline \multicolumn{4}{|l|}{ Miscellaneous invertebrate species } \\
\hline Anguinella palmata (brown bushy bryozoan), $\mathrm{n}=10$ & -19.2 & 9.0 & 14.3 \\
\hline Aurelia aurita (moon jelly), $\mathrm{n}=12$ & -19.5 & 15.0 & 19.6 \\
\hline Calliactis tricolor (hermit crab anemone), $\mathrm{n}=22$ & -16.0 & 12.0 & 16.7 \\
\hline Lolliguncula brevis (Atlantic brief squid), $\mathrm{n}=48$ & -17.8 & 15.7 & 15.7 \\
\hline Luida clathrata (grey sea star), $\mathrm{n}=7$ & -17.3 & 9.3 & 15.5 \\
\hline Mellita quinquiesperforata (sand dollar), $\mathrm{n}=99$ & -16.9 & 6.7 & 8.6 \\
\hline Polychaetes, $n>100$ & -17.7 & 11.6 & 13.5 \\
\hline \multicolumn{4}{|l|}{ Bivalves and gastropods } \\
\hline Busycon contrarum (lightning whelk), $\mathrm{n}=2$ & -17.1 & 11.6 & 16.7 \\
\hline Crepidula plana (white slipper snail), $\mathrm{n}=177$ & -19.3 & 8.7 & 13.0 \\
\hline Mercenaria campechiensis (southern quahog), $\mathrm{n}=2$ & -18.5 & 10.8 & 15.6 \\
\hline Nassarius vibex (eastern nassa snail), $\mathrm{n}=79$ & -16.3 & 14.1 & nd \\
\hline Pisania tincta (tinted cantharus), $\mathrm{n}=54$ & -19.2 & 12.6 & 13.7 \\
\hline Polynices duplicatus (Atlantic moon snail), $\mathrm{n}=1$ & -16.5 & 11.4 & 15.1 \\
\hline Tellina alternata (tellin clam), $\mathrm{n}=1$ & -19.2 & 7.5 & nd \\
\hline Thais haemastoma (rock snail), $\mathrm{n}=20$ & -16.6 & 13.7 & 15.7 \\
\hline
\end{tabular}

sional and hence their contribution to annual system production was negligible. Thus, although the stable isotope ratios of macroalgae and epiphytes were similar for all 3 elements examined, the former must be regarded as a purely opportunistic rather than a longterm food source for consumers in seagrass beds of Mississippi Sound.

Virtually all consumers sampled in this study had $\delta^{13} \mathrm{C}$ values that fell between -20 and $-15 \%$, with an overall average of $-17.3 \%$; this is very close to the average literature value of $-17.1 \%$ for organisms reported by Stribling \& Cornwell (1997). This range of values includes all $\delta^{13} \mathrm{C}$ values for epiphytes and sand microflora listed in Table 1, but none of those for either Halodule wrightii or phytoplankton. This strongly suggests that direct contribution of organic matter by $H$. wrightii to higher trophic levels of the food web was minimal relative to the biomass of seagrass versus epiphytes available to consumers within the system. An earlier study for the seagrasses in this locality (Moncreiff et al. 1992) showed that biomasses of seagrass and epiphytes are roughly equal when averaged over that part of the year during which data was collected. Using the pinfish Lagodon rhomboides $\left(\delta^{13} \mathrm{C}=\right.$ $-16.1 \%$ ) as an example for a 'mixing model' for $\delta^{13} \mathrm{C}$, and assuming equal contributions of seagrass and epiphytes, this organism would have a $\delta^{13} \mathrm{C}$ value of $-14.8 \%$. Setting contributions of seagrass at $25 \%$ and that of epiphytes at $75 \%$ would yield a $\delta^{13} \mathrm{C}$ value of $-16.2 \%$, which is nearly identical to the measured value for this organism. Equal contributions to $\delta^{13} \mathrm{C}$

\section{Trophic importance of benthic microalgae}

Plots employing $\delta^{13} \mathrm{C}$ and $\delta^{15} \mathrm{~N}$ values (Fig. 5) or $\delta^{13} \mathrm{C}$ and $\delta^{34} \mathrm{~S}$ values (Fig. 6) of primary producers and consumers from the Horn Island seagrass beds strongly argue in favor of a food web based on epiphytic algae, sand microflora, and macroalgae. Production rates of the first 2 primary producers are known to be substantial in these beds (see discussions in Daehnick et al. 1992 and Moncreiff et al. 1992). No attempt was made to determine primary production rates of macroalgae, since their occurrence in the beds was at best occa- from the sand microflora and from epiphytes would yield a $\delta^{13} \mathrm{C}$ value of $-16.6 \%$, again close to the measured value. Estimated $\delta^{13} \mathrm{C}$ would be $-15.2 \%$ for an organism consuming food items deriving nutrition equally from seagrass, epiphytes, and sand microflora, again less than the value observed for L. rhomboides, which can only be compensated for by increasing the relative contributions of epiphytes (or phytoplankton) to the base of this fish's diet. Thus, epiphytes would appear to make a larger contribution to this fish species' diet than relative biomass values for the primary producers would indicate. This could be a result of 
Table 3. Stable carbon isotope values (\%) for primary producers and consumers in seagrass systems

\begin{tabular}{|c|c|c|c|}
\hline Component & $\delta^{13} \mathrm{C}$ & Location & Source \\
\hline $\begin{array}{l}\text { Zostera marina } \\
\text { Epiphytes } \\
\text { Animals }\end{array}$ & $\begin{array}{c}-10 \\
-18 \text { to }-14 \\
-18 \text { to }-15\end{array}$ & North Carolina, USA & Thayer et al. (1978) \\
\hline $\begin{array}{l}\text { Syringodium filiforme } \\
\text { Thalassia testudinum } \\
\text { Halophila decipiens } \\
\text { Epiphytes } \\
\text { Animals }\end{array}$ & $\begin{array}{c}-5 \\
-10 \\
-9 \\
-12 \\
-16 \text { to }-9\end{array}$ & $\begin{array}{l}\text { St. Croix, US } \\
\text { Virgin Islands }\end{array}$ & Fry et al. (1982a) \\
\hline $\begin{array}{l}\text { Syringodium filiforme } \\
\text { Epiphytes } \\
\text { Animals }\end{array}$ & $\begin{array}{c}-8 \\
-22 \text { to }-17 \\
-22 \text { to }-16\end{array}$ & Florida, USA & Fry (1984) \\
\hline $\begin{array}{l}\text { Halodule wrightii } \\
\text { Syringodium filiforme } \\
\text { Thalassia testudinum } \\
\text { Epiphytes } \\
\text { Animals }\end{array}$ & $\begin{array}{l}-11 \text { to }-2 \\
-17 \text { to }-10 \\
-15 \text { to }-9\end{array}$ & Texas, USA & Kitting et al. (1984) \\
\hline $\begin{array}{l}\text { Posidonia australis } \\
\text { Heterozostera tasmanica } \\
\text { Epiphytes } \\
\text { Phytoplankton } \\
\text { Animals }\end{array}$ & $\begin{array}{c}-8 \\
-8 \\
-9 \\
-21 \\
-15 \text { to }-11\end{array}$ & Australia & Nichols et al. (1985) \\
\hline $\begin{array}{l}\text { Posidonia oceanica } \\
\text { Cymodocea nodosa } \\
\text { Epiphytes } \\
\text { Macroalgae } \\
\text { Phytoplankton } \\
\text { Animals }\end{array}$ & $\begin{array}{c}-8 \\
-9 \\
-20 \text { to }-14 \\
-31 \text { to }-10 \\
-23 \\
-24 \text { to }-14\end{array}$ & $\begin{array}{l}\text { Gulf of Calvi, } \\
\text { Corsica }\end{array}$ & Dauby (1989) \\
\hline $\begin{array}{l}\text { Thalassia testudinum } \\
\text { Syringodium filiforme } \\
\text { Epiphytes } \\
\text { Cyanobacteria mat } \\
\text { Macroalgae } \\
\text { Strombus gigas } \\
\text { Juveniles }(40-45 \mathrm{~mm}) \\
\text { Juveniles }(120-140 \mathrm{~mm})\end{array}$ & $\begin{array}{c}-5 \\
-3 \\
-16 \\
-19 \\
-17 \text { to }-11 \\
-11 \\
-10\end{array}$ & Bahamas & Stoner \& Waite (1991) \\
\hline $\begin{array}{l}\text { Posidonia oceanica } \\
\text { Epiphytes } \\
\text { Sand microflora } \\
\text { Macroalgae } \\
\text { Phytoplankton } \\
\text { Mysid shrimps }\end{array}$ & $\begin{array}{l}-12 \text { to }-9 \\
-17.5 \\
-18 \\
-20 \text { to }-16 \\
-24 \text { to }-20 \\
-20 \text { to }-17\end{array}$ & $\begin{array}{l}\text { Gulf of Calvi, } \\
\text { Corsica }\end{array}$ & Dauby (1995) \\
\hline $\begin{array}{l}\text { Enhalus acoroides } \\
\text { Halodule uninervis } \\
\text { Halophila ovalis } \\
\text { Epiphytes } \\
\text { Macroalgae } \\
\text { Seston } \\
\text { Juvenile prawns }\end{array}$ & $\begin{array}{c}-9 \\
-12 \\
-11 \\
-13 \\
-23 \text { to }-20 \\
-22 \text { to }-19 \\
-13 \text { to }-9\end{array}$ & $\begin{array}{c}\text { Gulf of Carpentaria, } \\
\text { Australia }\end{array}$ & Loneragan et al. (1997) \\
\hline $\begin{array}{l}\text { Syringodium isoetifolium } \\
\text { Epiphytes } \\
\text { Macroalgae } \\
\text { Herbivores }\end{array}$ & $\begin{array}{c}-5 \text { to }-3 \\
-14 \text { to }-13 \\
-13 \\
-17 \text { to }-10\end{array}$ & $\begin{array}{l}\text { Dravuni Island, } \\
\text { Fiji }\end{array}$ & Yamamuro (1999) \\
\hline $\begin{array}{l}\text { Halodule wrightii } \\
\text { Epiphytes } \\
\text { Sand microflora proxies } \\
\text { Macroalgae } \\
\text { Phytoplankton } \\
\text { Animals }\end{array}$ & $\begin{array}{l}-12 \\
-20 \text { to }-15 \\
-16 \\
-17 \\
-22 \\
-20 \text { to }-15\end{array}$ & Mississippi, USA & This study \\
\hline
\end{tabular}


preferential assimilation of algal material, selective grazing by organisms within the local food web, or greater available biomass during the year due to shorter turnover rates for epiphytes than for seagrasses (Borum 1987). Similar mixing models can be devised for most of the organisms sampled during this project with similar results: for most of the animals sampled, seagrass epiphytes and sand microflora contribute more to the base of the food web than $H$. wrightii. Contributions of the phytoplankton to the diets of seagrassassociated organisms is also likely to be much less than the contributions of epiphytic algae and the sand microflora. Therefore, one of the more important functions of $H$. wrightii in Mississippi Sound is to provide habitats with a 3-dimensional structure, and also to serve as attachment sites for the highly diverse and productive epiphytic algae (see Moncreiff et al. 1992), and habitat and structure for the sand- and seagrassassociated invertebrates that constitute the diets of many organisms within seagrass systems.

The mean $\delta^{13} \mathrm{C}$ values for epiphytes, sand microflora, and consumers were $-17.5,-15.8$, and $-17.3 \%$, respectively, whereas corresponding mean $\delta^{34} \mathrm{~S}$ values were $+18.2,+10.6$, and $+14.2 \%$, respectively. Using a mixing model approach with equal contributions to a $\delta^{34} \mathrm{~S}$ value for a hypothetical organism that would draw equally from seagrass, epiphytes, and sand microflora for its food web base, a $\delta^{34} \mathrm{~S}$ value of $+13.4 \%$ would be predicted. Again, on average, a larger contribution from epiphytes to the overall food web is needed to achieve the observed average $\delta^{34} \mathrm{~S}$ value for all organisms. Using the pinfish Lagodon rhomboides $\left(\delta^{34} \mathrm{~S}=\right.$ $+11.8 \%$ ) as an example, and assuming that $\delta^{34} \mathrm{~S}$ values of organisms mirror their diets, a mixing model for $\delta^{34} \mathrm{~S}$ would require a greater contribution from the sand microflora at the base of the components of the diet of this organism; in combination with its $\delta^{13} \mathrm{C}$ value, a diet based strongly on benthic organisms which consume sand microflora, plus additional contributions from epiphyte-based nutrition could be predicted. A large contribution from seagrass to the diet of this species is not supported by $\delta^{34} \mathrm{~S}$ values in combination with $\delta^{13} \mathrm{C}$ values; however, bacteria and yeasts that are often associated with the digestive systems of herbivorous fish species have been demonstrated to have cellulase activity, which may play a major role in the observed $\delta^{34} \mathrm{~S}$ value (Stickney \& Shumway 1974, Deegan et al. 1990). Cellulase activity in pinfish digestive tracts has been welldocumented by Luczkovich \& Stellwag (1993) and Stellwag et al. (1995).

With respect to the food web taken as a whole, the relatively low $\delta^{34} \mathrm{~S}$ values for the sand microflora proxies suggest that the epiphytic algae dominate the base of the food web in the Halodule wrightii beds of Mississippi Sound. Their annual production rates are

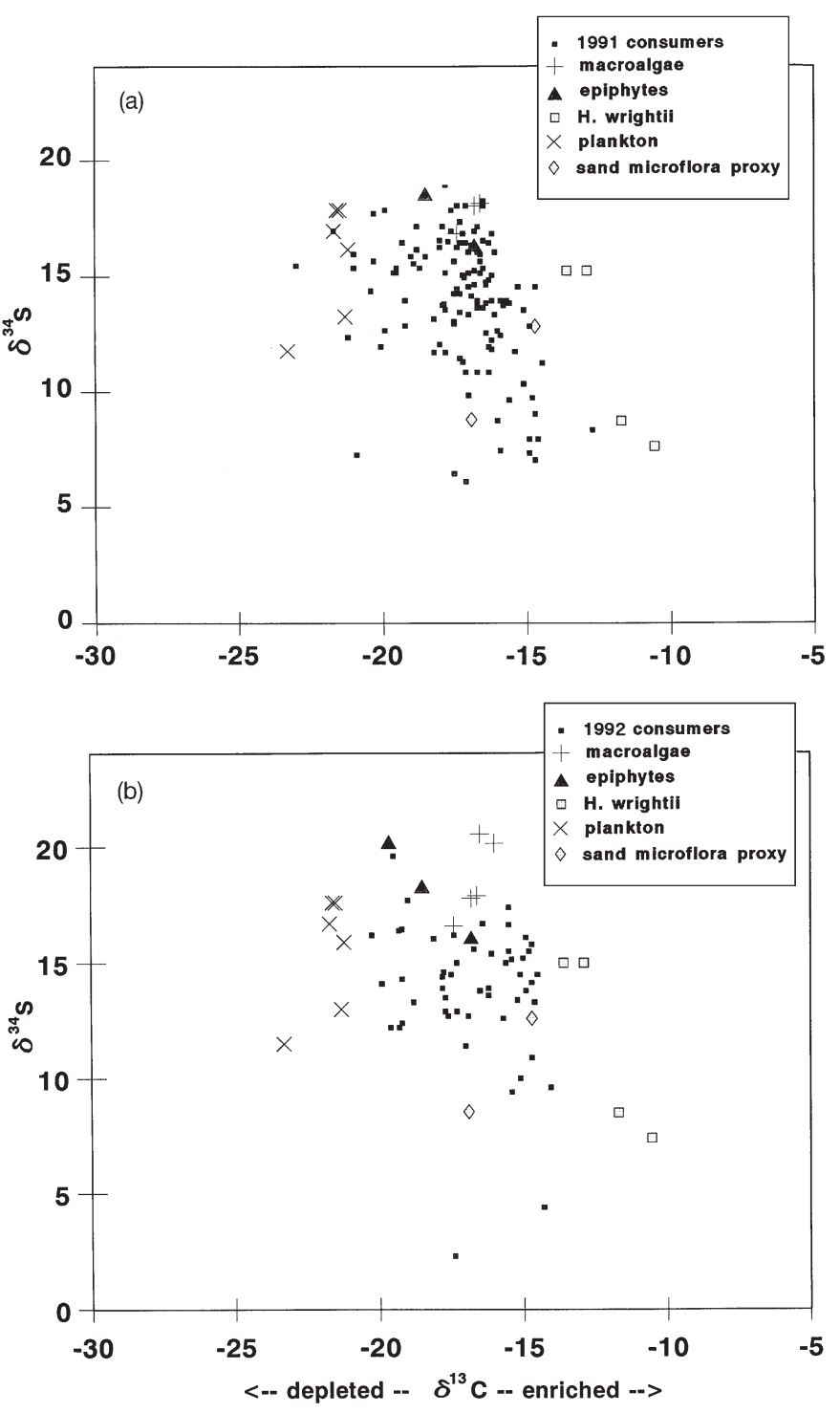

Fig. 6. Plots of $\delta^{13} \mathrm{C}$ vs $\delta^{34} \mathrm{~S}(\%)$ for primary producers and consumers collected from Horn Island seagrass beds in (a) 1991 and (b) 1992. Each small square represents an individual consumer sample

nearly 3 times greater than that of the sand microflora within these beds (Daehnick et al. 1992, Moncreiff et al. 1992). However, Fry et al. (1987) indicated that very little is known regarding the $\delta^{34} \mathrm{~S}$ values of sediment-associated microalgae and bacteria; the situation remains little changed today. These authors point out that low $\delta^{34} \mathrm{~S}$ values in consumers may well reflect consumption of benthic microflora rather than seagrasses, so that interpretations of food web dynamics based on $\delta^{34} \mathrm{~S}$ data must be made with caution. Stoner \& Waite (1991) employed stable isotope ratios of carbon and nitrogen to study organic matter sources for growth of juvenile queen conch Strombus gigas in the 
Bahamas. Although stomach contents revealed large amounts of seagrass detritus, $\delta^{13} \mathrm{C}$ values indicated that this detritus was not assimilated. $\delta^{13} \mathrm{C}$ values for conch foot muscle matched those of macroalgae (mainly the red algae in the genus Laurencia sp. and the green alga Batophora sp.) and sedimentary organic matter, the carbon sources used by this gastropod for growth. In the case of the sediments, it was suggested that juvenile conch process large amounts of sand to extract diatoms and other organic matter from the surface sediments. Hence, the importance of the sand microflora to the food web in $H$. wrightii beds of Mississippi Sound may be much greater than suggested by $\delta^{34} \mathrm{~S}$ data alone.

Recent work employing multiple stable isotope ratios $\left(\delta^{13} \mathrm{C}, \delta^{15} \mathrm{~N}, \delta^{34} \mathrm{~S}\right)$ has confirmed the importance of the microscopic benthic algae in salt-marsh food webs, although vascular plants do contribute as much as $50 \%$ to the nutrition of consumers in some systems (Peterson \& Howarth 1987, Sullivan \& Moncreiff 1990, Currin et al. 1995, Kwak \& Zedler 1997). Dependence on seagrasses and their associated macroalgae as organic matter sources for fishes has also been documented using $\delta^{13} \mathrm{C}$ and $\delta^{15} \mathrm{~N}$ (Marguillier et al. 1997). The present report represents the first systematic application of the multiple stable isotope approach to the study of food webs in seagrass beds, and the importance of the benthic microalgae has also been confirmed in this system. Contributions from the dominant vascular plant in this study to overall consumer nutrition appear to be substantially less than those observed in salt-marsh ecosystems. Furthermore, systems such as the one we studied, which are characterized by low tidal amplitude typically have an algae-based food web (Deegan \& Garritt 1997).

A progression of stable isotope studies since that of Thayer et al. (1978) has established a new paradigm for food web structure in seagrass systems, and these are summarized in Table 3. Similar results for the importance of algal as opposed to detrital carbon sources have been found in mangrove and mangroveseagrass systems (Newell et al. 1995, Primavera 1996). Fry et al. (1982a) had earlier suggested that animals feeding in seagrass beds ingest and assimilate epiphytic algae rather than seagrass leaves. Klumpp et al. (1992) reported that 20 to $62 \%$ of the net production of epiphytes was consumed by epifaunal organisms in a tropical seagrass bed, and concluded that epiphytic algae played a major role in the trophic flux of this system. With the exception of the studies of Nichols et al. (1985) and Loneragan et al. (1997), all studies listed in Table 3 that determined stable isotope ratios for a diversity of animals occupying different trophic levels demonstrate the striking similarity in $\delta^{13} \mathrm{C}$ values between epiphytic algae and consumers. In most cases, $\delta^{13} \mathrm{C}$ values for seagrass leaves are quite distinct from those of consumers (Table 3). Kitting et al. (1984) found that animal $\delta^{13} \mathrm{C}$ values tracked epiphyte values, and their remote sensing of grazing activities affirmed that invertebrates fed primarily on epiphytic algae, even when such algae were scarce, with very little feeding on seagrass leaves or detritus. As in the seagrass beds of Mississippi Sound, the biomass and primary production rates of the epiphytic algae are very high, providing an abundant food source for grazers; therefore, epiphytic algae in these 2 systems at least are the primary basis of the food web.

Fry et al. (1987) emphasized that nutrient availability may govern the trophic importance of epiphytic algae in seagrass meadows. Eutrophic conditions would favor food webs based on algae whereas oligotrophic conditions would favor seagrass detritus (but see Yamamuro 1999). Production of organic matter by epiphytic algae has been shown to equal or exceed that of their seagrass hosts in temperate (Thom 1990), subtropical (Morgan \& Kitting 1984, Moncreiff et al. 1992), and tropical (Klumpp et al. 1992, Loneragan et al. 1997) systems. In such cases, the epiphytic algae (dominated by diatoms in our system) represent a reliable and highly nutritious food source (Montagna 1984, Gleason 1986, Plante-Cuny \& Plante 1986, Decho 1988, Klumpp et al. 1992, Jernakoff et al. 1996, Créach et al. 1997). Even in more oligotrophic conditions, epiphytic algae may nonetheless be trophically important because diatoms can completely coat seagrass leaves, forming an 'epiphytic felt' (Dauby \& Poulicek 1995) and yet be invisible to the naked eye (see Fig. 2 in Koch 1994 and Fig. 1 in Dauby \& Poulicek 1995). Furthermore, the benthic microalgae in sandy sediments (which is typically dominated by diatoms; Rao \& Lewin 1976, Sundbäck 1983, 1984, Delgado 1989, Dauby 1995) may also contribute significantly to the food web in seagrass systems. A significant portion of water column productivity (i.e. 'phytoplankton' production) in shallow systems may sometimes be due to displaced benthic diatoms and other microalgae (Riaux-Gobin 1987, Shaffer \& Sullivan 1988). A recently completed ecosystem-network analysis by Christian \& Luczkovich (1999) strongly suggests a major role for sediment-associated microalgae in Halodule wrightii meadows in nearby Apalachee Bay, Florida. Since the diatom taxa epiphytic on seagrass leaves and in the sediments are different (Sullivan 1979, Daehnick et al. 1992, Moncreiff et al. 1992), a determination of the identity and abundance of diatoms in the guts of primary consumers would help address this question. At present, the overall picture that has emerged is one of the major trophic importance of benthic microalgae in seagrass beds. 
Acknowledgements. This work is a result of research sponsored in part by the National Oceanic and Atmospheric Administration, US Department of Commerce, under Grant \#NA16RG0155-02, the Mississippi-Alabama Sea Grant Consortium and Mississippi State University. The US Government and the Mississippi-Alabama Sea Grant Consortium are authorized to produce and distribute reprints notwithstanding any copyright notation that may appear hereon. The views expressed herein are those of the authors and do not necessarily reflect the views of NOAA or any of its subagencies.

\section{LITERATURE CITED}

Ballantine D, Humm HJ (1975) Benthic algae of the Anclote Estuary. I. Epiphytes of seagrass leaves. FL Sci 38:150-162

Borum J (1987) Dynamics of epiphyton on eelgrass (Zostera marina L.) leaves: relative roles of algal growth, herbivory and substratum turnover. Limnol Oceanogr 32: 986-992

Boschker HTS, de Brouwer JFC, Cappenberg TE (1999) The contribution of macrophyte-derived organic matter to microbial biomass in salt-marsh sediments: stable carbon isotope analysis of microbial biomarkers. Limnol Oceanogr 44:309-319

Bunn SE, Loneragan NR, Kempster MA (1995) Effects of acid washing on stable isotope ratios of $\mathrm{C}$ and $\mathrm{N}$ in penaeid shrimp and seagrass: implications for food-web studies using multiple stable isotopes. Limnol Oceanogr 40: 622-625

Chanton JP, Lewis FG (1999) Plankton and dissolved inorganic carbon isotopic composition in a river-dominated estuary, Apalachicola Bay, FL. Estuaries 22:575-583

Christian RR, Luczkovich JJ (1999) Organizing and understanding a winter's seagrass foodweb network through effective trophic levels. Ecol Model 117:99-124

Créach V, Schricke MT, Bertru G, Mariotti A (1997) Stable isotopes and gut analyses to determine feeding relationships in saltmarsh macroconsumers. Estuar Coast Shelf Sci 44:599-611

Currin CA, Newell SY, Paerl, HW (1995) The role of standing dead Spartina alterniflora and benthic microalgae in salt marsh food webs: considerations based on multiple stable isotope analysis. Mar Ecol Prog Ser 121:99-116

Daehnick AE, Sullivan MJ, Moncreiff CA (1992) Primary production of the sand microflora in seagrass beds of Mississippi Sound. Bot Mar 35:131-139

Dauby P (1989) The stable carbon isotope ratios in benthic food webs of the Gulf of Calvi, Corsica. Contin Shelf Res 9: 181-195

Dauby P (1995) A $\delta^{13} \mathrm{C}$ study of the feeding habits in four Mediterranean Leptomysis species (Crustacea: Mysidacea). PSZN I: Mar Ecol 16:93-102

Dauby P, Poulicek M (1995) Methods for removing epiphytes from seagrasses: SEM observations on treated leaves. Aquat Bot 52:217-228

Decho AW (1988) How do harpacticoid grazing rates differ over a tidal cycle? Field verification using chlorophyll pigment analysis. Mar Ecol Prog Ser 45:263-270

Deegan LA, Garritt RH (1997) Evidence for spatial variability in estuarine food webs. Mar Ecol Prog Ser 147:31-47

Deegan LA, Peterson BJ, Portier R (1990) Stable isotopes and cellulase activity as evidence for detritus as a food source for juvenile Gulf menhaden. Estuaries 13:14-19

Delgado M (1989) Abundance and distribution of microphytobenthos in the bays of Ebro Delta (Spain). Estuar Coast Shelf Sci 29:183-194
DeNiro MJ, Epstein S (1978) Influence of diet on the distribution of carbon isotopes in animals. Geochim Cosmochim Acta 42:495-506

Fry $\mathrm{B}(1984) \delta^{13} \mathrm{C} /{ }^{12} \mathrm{C}$ ratios and the trophic importance of algae in Florida Syringodium filiforme seagrass meadows. Mar Biol 79:11-19

Fry B, Sherr EB (1984) $\delta^{13} \mathrm{C}$ measurements as indicators of carbon flow in marine and freshwater ecosystems. Contrib Mar Sci 27:13-47

Fry B, Lutes R, Northam M, Parker PL, Ogden J (1982a) A $\delta^{13} \mathrm{C} /{ }^{12} \mathrm{C}$ comparison of food webs in Caribbean seagrass meadows and coral reefs. Aquat Bot 14:389-398

Fry B, Scalan RS, Winters JK, Parker PL (1982b) Sulphur uptake by salt grasses, mangroves, and seagrasses in anaerobic sediments. Geochim Cosmochim Acta 46: 1121-1124

Fry B, Macko SA, Zieman JC (1987) Review of stable isotopic investigations of food webs in seagrass meadows. In: Durako MJ, Phillips RC, Lewis RR (eds) Proceedings of a Symposium on Subtropical-Tropical Seagrasses, Southeast United States. Florida Department of Natural Resources, Bureau of Marine Research, St. Petersburg, p 117-138 (Florida Mar Resources Publ No. 42)

Gleason DF (1986) Utilization of salt marsh plants by postlarval brown shrimp: carbon assimilation rates and food preferences. Mar Ecol Prog Ser 31:151-158

Gosner KL (1971) Guide to the identification of marine and estuarine invertebrates. John Wiley \& Sons, New York

Hemminga MA, Mateo MA (1996) Stable carbon isotopes in seagrasses: variability in ratios and use in ecological studies. Mar Ecol Prog Ser 140:285-298

Hobson KA, Welch HE (1992) Determination of trophic relationships within a high Arctic marine food web using $\delta^{13} \mathrm{C}$ and $\delta^{15} \mathrm{~N}$ analysis. Mar Ecol Prog Ser 84:9-18

Humm HJ (1964) Epiphytes of the seagrass Thalassia testudinum in Florida. Bull Mar Sci Gulf Caribb 14:306-341

Jernakoff P, Nielsen J (1997) The relative importance of amphipod and gastropod grazers in Posidonia sinuosa meadows. Aquat Bot 56:183-202

Jernakoff P, Brearley A, Nielsen J (1996) Factors affecting grazer-epiphyte interactions in temperate seagrass meadows. Oceanogr Mar Biol Annu Rev 34:109-162

Kitting CL (1984) Selectivity by dense populations of small invertebrates foraging among seagrass blade surfaces. Estuaries 7:276-288

Kitting CL, Fry B, Morgan MD (1984) Detection of inconspicuous epiphytic algae supporting food webs in seagrass meadows. Oecologia (Berl) 62:145-149

Klumpp DW, Salita-Espinosa JS, Fortes MD (1992) The role of epiphytic periphyton and macroinvertebrate grazers in the trophic flux of a tropical seagrass community. Aquat Bot 43:327-349

Koch EW (1994) Hydrodynamics, diffusion-boundary layers and photosynthesis of the seagrasses Thalassia testudinum and Cymodocea nodosa. Mar Biol 118:767-776

Kwak TJ, Zedler JB (1997) Food web analysis of southern California coastal wetlands using multiple stable isotopes. Oecologia (Berl) 110:262-277

Loneragan NR, Bunn SE, Kellaway DM (1997) Are mangroves and seagrasses sources of organic carbon for penaeid prawns in a tropical Australian estuary? A multiple stable isotope study. Mar Biol 130:289-300

Luczkovich JJ, Stellwag EJ (1993) Isolation of cellulolytic microbes from the intestinal tract of the pinfish, Lagodon rhomboides: size-related changes in diet and microbial abundance. Mar Biol 116:381-388

MacGinitie GE, MacGinitie N (1949) Natural history of 
marine animals, 1st edn. McGraw-Hill Book Co., Inc, New York

Marguillier S, van der Velde G, Dehairs F, Hemminga MA, Rajagopal S (1997) Trophic relationships in an interlinked mangrove-seagrass ecosystem as traced by $\delta^{13} \mathrm{C}$ and $\delta^{15} \mathrm{~N}$. Mar Ecol Prog Ser 151:115-121

McMillan C, Parker PL, Fry B $(1980){ }^{13} \mathrm{C} /{ }^{12} \mathrm{C}$ ratios in seagrasses. Aquat Bot 9:237-249

Moncreiff CA, Sullivan MJ, Daehnick AE (1992) Primary production dynamics in seagrass beds of Mississippi Sound: the contributions of seagrass, epiphytic algae, sand microflora, and phytoplankton. Mar Ecol Prog Ser 87: 161-171

Montagna, PA (1984) In situ measurement of meiobenthic grazing rates on sediment bacteria and edaphic diatoms. Mar Ecol Prog Ser 18:119-130

Morgan MD, Kitting CL (1984) Production and utilization of the seagrass Halodule wrightii and its attached epiphytes. Limnol Oceanogr 29:1066-1076

Newell RIE, Marshall N, Sasekumar A, Chong VC (1995) Relative importance of benthic microalgae, phytoplankton, and mangroves as sources of nutrition for penaeid prawns and other coastal invertebrates from Malaysia. Mar Biol 123:595-606

Nichols PD, Klumpp DW, Johns RB (1985) A study of food chains in seagrass communities III. Stable carbon isotope ratios. Aust J Mar Freshw Res 36:683-690

Peterson BJ, Howarth RW (1987) Sulfur, carbon, and nitrogen isotopes used to trace organic matter flow in the saltmarsh estuaries of Sapelo Island, Georgia. Limnol Oceanogr 32:1195-1213

Peterson BJ, Howarth RW, Garritt, RH (1985) Multiple stable isotopes used to trace the flow of organic matter in estuarine food webs. Science 227:1361-1363

Peterson BJ, Howarth RW, Garritt RH (1986) Sulfur and carbon isotopes as tracers of salt-marsh organic matter flow. Ecology 67:865-874

Plante-Cuny MR, Plante R (1986) Benthic marine diatoms as food for benthic marine animals. In: Ricard M (ed) Proceedings of the Eigth International Diatom Symposium, Paris, 1984. S. Koeltz, Koenigstein, p 525-527

Pollard PC, Kogure K (1993) The role of epiphytic and epibenthic algal productivity in a tropical seagrass, Syringodium isoetifolium (Aschers.) Dandy, community. Aust J Mar Freshw Res 44:141-154

Primavera JH (1996) Stable carbon and nitrogen isotope ratios of penaeid juveniles and primary producers in a riverine mangrove in Guimaras, Philippines. Bull Mar Sci 58: 675-683

Rao VNR, Lewin J (1976) Benthic marine diatom flora of False Bay San Juan Island, Washington. Syesis 9:173-213

Riaux-Gobin C (1987) Phytoplancton, tripton et microphyto-

Editorial responsibility: Otto Kinne (Editor),

Oldendorf/Luhe, Germany benthos: échanges au cours de la marée, dans un estuaire du Nord-Finistère. Cah Biol Mar 28:159-184

Ruppert EE, Fox RS (1988) Seashore animals of the southeast. University of South Carolina Press, Columbia

Shaffer GP, Sullivan MJ (1988) Water column productivity attributable to displaced benthic diatoms in well-mixed shallow estuaries. J Phycol 24:132-140

Stellwag EJ, Smith TD, Luczkovich JJ (1995) Characterization and ecology of carboxymethylcellulase-producing anaerobic bacterial communities associated with the intestinal tract of the pinfish, Lagodon rhomboides. Appl Environ Microbiol 61:813-816

Stickney RR, Shumway SE (1974) Occurrence of cellulase activity in the stomachs of fishes. J Fish Biol 6:779-790

Stoner AW, Waite JM (1991) Trophic biology of Strombas gigas in nursery habitats: diets and food sources in seagrass meadows. J Molluscan Stud 57:543-551

Stribling JM, Cornwell JC (1997) Identification of important primary producers in a Chesapeake Bay tidal creek system using stable isotopes of carbon and sulfur. Estuaries $20: 77-85$

Sullivan MJ (1979) Epiphytic diatoms of three seagrass species in Mississippi Sound. Bull Mar Sci 29:459-464

Sullivan MJ, Moncreiff CA (1990) Edaphic algae are an important component of salt marsh food webs: evidence from multiple stable isotope analyses. Mar Ecol Prog Ser 62:149-159

Sullivan MJ, Moncreiff CA (1993) Trophic importance of epiphytic algae in Mississippi seagrass beds. MississippiAlabama Sea Grant Consortium, Ocean Springs, MS (Mississippi-Alabama Sea Grant Publ No MASGP-92-018)

Sundbäck K (1983) Microphytobenthos on sand in shallow brackish water, Öresund, Sweden. Primary production, chlorophyll a content and species composition (diatoms) in relation to some ecological factors. PhD dissertation. University of Lund, Lund

Sundbäck K (1984) Distribution of microbenthic chlorophyll-a and diatom species related to sediment characteristics. Ophelia (Suppl) 3:229-246

Thayer GW, Parker PL, LaCroix MW, Fry B (1978) The stable carbon isotope ratio of some components of an eelgrass, Zostera marina, bed. Oecologia (Berl) 35:1-12

Thom RM (1990) Spatial and temporal patterns in plant breeding stock and primary production in a temperate seagrass system. Bot Mar 33:497-510

Thursby GB, Davis JS (1984) Species composition and relative abundance of attached diatoms and other algae in the coastal waters adjacent to Seahorse Key, Florida. FL Sci 47:130-140

Yamamuro M (1999) Importance of epiphytic cyanobacteria as food sources for heterotrophs in a tropical seagrass bed. Coral Reefs 18:263-271

Submitted: December 6, 1999; Accepted: September 6, 2000 Proofs received from author(s): April 18, 2001 